\title{
PENGARUH FAKTOR-FAKTOR PRODUKSI TERHADAP TINGKAT KEUNTUNGAN PENGUSAHA KAYU DI KOTA BAUBAU
}

\author{
Antasalam Ajo ${ }^{1}$ ), La Ode Muhamad Harudin ${ }^{2}$ ) \\ Program Studi Agribisnis Fakultas Pertanian UM. Buton \\ UPTD KPH Unit 2 Lasalimu, Kabupaten Buton, Provinsi Sulawesi Tenggara \\ Email: antasalampk@yahoo.com
}

\begin{abstract}
To human beings, wood is a significant forest material. Without wood, people will have difficulties in meeting the living needs of wood and its production to have economic and sustainable quality. The goal of the analysis was to determine, partially and simultaneously, the effect of resources, the number of workers, the length of business and fuel on the profitability of wood-makers in the City of Baubau. The data obtained were analyzed with several linear regression equations $T$ testing and $F$ testing to measure the effect. The results showed that capital has a positive and significant impact on entrepreneurs 'income rates so that capital availability is very important. While the number of workers, the duration and the fuel volumes do not affect the profitability of wood entrepreneurs, the three variables were not taken into account as the main factors in increasing levels of profits. At the same time, the profitability of timber contractors did not affect resources, the number of employees, the duration of business and the amount of fuel. Adjusted R2 by 0.375 means that only $37.5 \%$ of the wood contractor's income is influenced by the factors measured in the report.
\end{abstract}

Keywords: Processed wood, forest products, profits

\begin{abstract}
Abstrak
Kayu merupakan produk hasil hutan yang penting bagi manusia. Tanpa kayu, manusia akan mengalami kesulitan dalam memenuhi kebutuhan hidup sehingga diperlukan pengelolaan kayu dan olahannya dengan baik agar bernilai ekonomis dan lestari.Tujuan dari penelitian ini adalah mengetahui pengaruh modal, jumlah tenaga kerja, lama berusaha, dan jumlah bahan bakar terhadap tingkat keuntungan pengusaha kayu di Kota Baubau baik secara parsial maupun simultan. Data-data yang diperoleh dianalisis untuk mengukur pengaruhnya menggunakan rumus regresi linear berganda dan uji t serta uji F. Hasil penelitian menemukan bahwa modal memberikan pengaruh secara positif dan signifikan terhadap tingkat keuntungan pengusaha sehingga ketersediaan modal sangat penting. Sedangkan jumlah tenaga kerja, lama berusaha dan jumlah bahan bakar masing-masing tidak memberikan pengaruh terhadap tingkat keuntungan pengusaha kayu, karena ketiga variabel tersebut belum dianggap sebagai faktor utama dalam meningkatkan tingkat keuntungan. Secara simultan modal, jumlah tenaga kerja, lama berusaha dan jumlah bahan bakar juga tidak berpengaruh terhadap tingkat keuntungan pengusaha kayu. Nilai Adjusted $\mathrm{R}^{2}$ sebesar 0,375 berarti faktor-faktor yang diukur dalam penelitian hanya berpengaruh sebesar 37,5\% terhadap terhadap keuntungan pengusaha kayu.
\end{abstract}


Kata kunci: Olahan kayu, hasil hutan, keuntungan

\section{PENDAHULUAN}

Kebutuhan kayu semakin meningkat seiring dengan peningkatan jumlah penduduk. Hal ini disebabkan kayu dan hasil olahan kayu merupakan produk penting dan sangat bermanfaat bagi manusia. Pemanfaatan kayu antara lain untuk kebutuhan rumah tangga mulai dari membangun rumah, perkantoran, hingga industri seperti pengadaan furniture, dan berbagai kebutuhan lain. Seiring permintaan terhadap kayu yang semakin meningkat, menyebabkan manusia berfikir untuk mencari pengganti produk selain kayu. Sebagaimana dijelaskan oleh Ruhendi, (1988) dalam Sopianoor, Zuhdi dan Biantary (2016) bahwa dalam proses pengolahan kayu yang disebut industri kayu primer adalah industri penggergajian, karena proses penggergajian merupakan yang pertama kali yang merubah kayu (dalam bentuk log) menjadi kayu gergajian (sawn timber atau kayu konversi) yang berupa balok, papan, tiang, bantalan, dan dalam bentuk sortimen lainnya. Fungsi kegiatan penggergajian adalah merubah log menjadi kayu yang mempunyai ukuran tertentu sesuai dengan tujuan pemakaian melalui proses pembelahan dan pemotongan. Ia juga berfungsi meningkatkan nilai atau kualitas kayu dengan cara menghilangkan bagian yang cacat atau membuat sortimen tertentu yang nilainya lebih tinggi. Seiring perkembangan waktu, karena pertambahan jumlah penduduk, dan pengalihan fungsi lahan untuk keperluan lain selain hutan menyebabkan penurunan jumlah produksi kayu. Menurut Djoko (2011) bahwa di Kalimantan Selatan, pada tahun 2001 produksi kayu gergajian mencapai 2.183.154,939 $\mathrm{m}^{3}$, kemudian pada tahun 2002 mengalami penurunan, yaitu menjadi $357.513 .046 \mathrm{~m}^{3}$ (Dinas Kehutanan Propinsi Kalimantan Selatan, 2003). Penurunan produksi diperkirakan karena keberadaan potensi alam semakin berkurang, dan kondisi ini akan berdampak terhadap kebutuhan balok dan papan yang digunakan untuk bahan bangunan dan mebel bagi masyarakat.

Pengusaha penampung kayu di Kota Baubau termasuk industri kecil, karena memiliki ciri-ciri seperti yang dikemukakan oleh Mubyarto (1997) dalam Afifah, 2012) adalah sebagai berikut:

1. Jumlah tenaga kerja kurang dari 5-9 orang.

2. Kebanyakan tenaga kerja diperoleh dari lingkungan atau dekat dengan lokasi industri.

3. Teknologi yang digunakan bersifat sederhana dan lebih banyak menggunakan tenaga tangan.

4. Bahan dasar umumnya di dapat dari daerah sekitarnya.

Penelitian ini berfokus pada pengusaha kayu di Kota Baubau yang menjual kayu dalam bentuk produk setengah jadi seperti papan dan balok, khususnya di Kecamatan Murhum dan Kecamatan Wolio yang merupakan pusat aktivitas para pengusaha kayu, yang memperdagangkan kayu baik kayu balok maupun dalam bentuk papan dari berbagai jenis kayu yang ada. Para pengusaha tersebut selama ini menopang industri pengolahan kayu di Kota Baubau dan sekitarnya. Usaha pengolahan kayu biasa diolah terlebih dahulu yang disebut dengan sistem pengolahan awal (primer), walaupun ada juga yang melakukan pengolahan sekunder seperti sebagian pengusaha kayu di Baubau tepatnya di Jalan Bataraguru Kecamatan Wolio, karena teknik pengolahannya menggunakan teknologi dan biaya yang tinggi.

Industri kecil berbahan baku kayu biasanya juga banyak memiliki hambatan dalam hal permodalan, penggunaan teknologi yang terbatas, dan lain-lain terutama di lokasi 
penelitian. Karena itu faktor-faktor seperti masalah permodalan, tenaga kerja, bahan baku dan bahan bakar, yang dinilai berperan serta meningkatkan jumlah pendapatan pengusaha kayu, maka perlu didalami sebab menentukan maju mundurnya suatu usaha proses produksi. Maka penting kiranya penelitian ini untuk mendalami lebih agar penggunaan berbagai faktor tersebut yang mempengaruhi tingkat pendapatan pengusaha kayu lebih optimal lagi pada masa-masa yang akan datang.

Tujuan dari penelitian ini adalah mengetahui pengaruh modal, jumlah tenaga kerja, lama berusaha, dan jumlah bahan bakar terhadap tingkat keuntungan pengusaha kayu di Kota Baubau. Pengukurannya adalah baik secara parsial maupun secara simultan.

\section{Kayu}

\section{TINJAUAN PUSTAKA}

Kayu banyak macamnya. Menurut Jane (1955) dalam Yustinus (2012) dari seluruh komunitas kayu di dunia ini dibedakan secara anatomis menjadi dua kelompok, yaitu kayukeras dan kayu-lunak. Kayu keras adalah kayu yang memiliki pori atau pembuluh, sedangkan kayu lunak adalah kayu yang tidak memiliki pembuluh. Pembuluh merupakan salah satu elemen anatomis kayu. Selain pembuluh, elemen kayu secara anatomis ini meliputi serabut, trakeid, parenkim, jari-jari, dan saluran damar.

Bila terminologi "kayu keras" dilihat dalam konteks sifat kayu, maka terminologi "kayu keras" menunjuk pada kayu yang memiliki tingkat kekerasan yang tinggi. Sebaliknya ada "kayu lunak", yang menunjuk pada kayu yang memiliki tingkat kekerasan tingkat moderat. Dengan demikian, tingkat kekerasan kayu merupakan salah satu sifat kayu (Yustinus, 2012).

Teknologi penggergajian yang banyak diterapkan dan dipakai oleh masyarakat untuk mendapatkan ukuran sortimen biasanya menggunakan dua macam pola, pertama pembelahan satu sisi (live sawing), yaitu pola dengan irisan gergaji pada permukaan lebar kayu menyinggung lingkaran tahun. Pola ini menghasilkan papan tangensial yang tidak sebanding pada arah radial dan tangensialnya. Pola penggergajian kedua ialah sistem perempatan (quarter sawing), yaitu pola dengan irisan gergaji membentuk sudut tegak lurus atau hamper lurus dengan lingkaran tahun, yang menghasilkan papan radial yang lebih stabil dimensinya. Pola lain yang belum banyak diketahui dan digunakan oleh masyarakat adalah pola semi/setengah perempatan (Siarudin dan Widiyanto, 2012).

$\begin{array}{cccccc}\text { Batang } & \text { kayu jati yang dipotong melintang akan memperlihatkan } \\ \text { bagian-bagian } & \text { kayu, yang kerap kali } & \text { berbeda } & \text { warna. } & \text { Bagian-bagian }\end{array}$ tersebut antara lain (Rachman, Malik, 2011) yaitu:

a. Kulit. Kulit kayu jati adalah bagian yang terdapat pada bagian terluar yang berfungsi sebagai pelindung bagian-bagian yang terdalam, terhadap kemungkinan pengaruh dari luar yang bersifat merusak, misalnya iklim, serangan serangga, hama, kebakaran serta perusak kayu lainnya.

b. Gubal, bagian kayu yang masih muda terdiri dari sel-sel yang masih hidup yang berfungsi sebagai penyalur cairan dan tempat penimbunan zat-zat makanan. Tebal lapisan kayu gubal bervariasi menurut jenis pohon.

c. Teras merupakan bagian dari kayu yang berupa penumpukan sel-sel yang telah mati dan secara fisiologis selnya sudah tidak berfungsi. Kayu teras berwarna lebih tua dari bagian gubalnya, karena kandungan zat ekstraktif dalam kayu teras lebih 
tinggi. Zat ekstraktif mempunyai fungsi penting dalam menjaga keawetan alami kayu, sehingga tidak mudah terserang organism perusak kayu. Dalam hal ini, kayu teras lebih tahan terhadap serangan organisme perusak kayu daripada kayu gubalnya (Butterfield, 1993).

d. Empulur Empulur merupakan jaringan lunak yang akan mengeras pada saat batang tumbuh dewasa. Empulur semakin membesar diameternya searah tinggi pohon, dengan kata lain semakin tinggi pohon, maka bagian empulurnya semakin membesar (Wilson and White, 1986).

\section{Modal}

Modal yang merupakan salah satu faktor produksi akan menentukan produktivitas perusahaan. Teori Cobb-Douglas yang menyatakan bahwa modal mempengaruhi output produksi. Kondisi ini menunjukkan semakin tinggi modal akan dapat meningkatkan hasil produksi, karena dalam proses produksi membutuhkan biaya yang digunakan untuk tenaga kerja dan pembelian bahan baku serta peralatan (Sulistiana, 2013 dalam Komang dan Kartika, 2018).

Salah satu faktor produksi yang penting adalah modal, karena tanpa modal kegiatan usaha tidak akan dapat berjalan dengan baik seperti yang diharapkan oleh para pengusaha baik kecil maupun besar. Untuk dapat memenuhi kewajiban terhadap tenaga kerja saja, maka pengusaha harus memberikan upah yang diperoleh dari modal untuk membayarnya. Sumber dari modal usaha itu dapat bersumber dari modal sendiri dan modal dari luar, dimana modal harus

dimaksimalkan dengan baik kegunaannya (Zhou Gideon, 2013 dalam Komang dan Kartika, 2018).

Biasanya modal bisa digunakan sekaligus sebagai investasi. Investasi dapat diartikan sebagai pengeluaran atau pembelanjaan penanaman-penanaman modal atau perusahaan untuk membeli barang-barang modal dan perlengkapan-perlengkapan produksi untuk menambah kemampuan memproduksi barang-barang dan jasa-jasa yang tersedia dalam perekonomian .

\section{Tenaga Kerja}

Tenaga kerja adalah setiap orang, yang mampu melakukan pekerjaan guna menghasilkan barang dan atau jasa baik untuk memenuhi kebutuhan masyarakat. Sedangkan ketenagakerjaan adalah segala hal yang berhubungan dengan tenaga kerja pada waktu sebelum, selama, dan sesudah masa kerja. hal yang berkaitan sebelum bekerja adalah antara lain membekali seseorang dengan keterampilan khusus melalui program pelatihan, penyediaan informasi pasar kerja, pemberian bimbingan dan penyuluhan jabatan, serta pengerahan untuk penempatan. Hal yang berkaitan selama bekerja mencakup penempatan, pengupahan, peningkatan produktivitas, hubungan industrial, keselamatan dan kesehatan kerja, perlindungan dan lain-lain. Hal yang berkaitan sesudah masa kerja mencakup jaminan hari tua (Simanjuntak, 2003 dalam Marselina, 2016).

Tenaga kerja merupakan faktor pendapatan yang sangat penting dan diperhatikan dalam proses produksi dan dalam jumlah yang cukup, bukan saja dilihat dari ketersediaannya tapi kualitas dan macam-macamnya. Menurut Rizki (2017) setiap proses produksi harus disediakan tenaga kerja yang cukup memadai, jumlah tenaga kerja yang digunakan harus disesuaikan dengan kebutuhan sampai tingkat tertentu sehingga optimal. 
Tenaga kerja merupakan faktor penggerak faktor input yang lain. Dengan meningkatnya produktifitas tenaga kerja akan mendorong peningkatan produksi sehingga pendapatan pun akan ikut meningkat. Sesuai pendapat Rizki (2017) bahwa tenaga kerja merupakan faktor produksi terpenting dalam suatu unit usaha.

\section{Lama Berusaha}

Lama berusaha dapat mempengaruhi tingkat pendapatan dan akan mempengaruhi produktivitasnya (kemampuan profesionalnya/keahliannya), sehingga dapat menambah efisiensi dan mampu menekan biaya produksi lebih kecil daripada hasil penjualan. Semakin lama menekuni bidang usaha perdagangan akan makin meningkatkan pengetahuan tentang selera ataupun perilaku konsumen (Wicaksono, 2011 dalam Faizal, 2017).

Pengelolaan usaha dalam sektor informal sangat dipengaruhi oleh tingkat kecakapan manajemen yang baik dalam pengelolaan usaha yang dimiliki oleh seorang pengusaha. Tingkat kecakapan manajemen yang baik ini juga sangat dipengaruhi oleh pengalaman atau lama berusaha seorang pedagang (Fachmi, 2014).

Keahlian keusahawaan merupakan "kemampuan yang dimiliki seseorang untuk mengorganisasikan dan menggunakan faktor-faktor lain dalam kegiatan memproduksi barang dan jasa yang diperlukan masyarakat" Sukirno, (1994) dalam Sofyan, 2017). Foster (2001) dalam Fachmi, 2014) mengatakan ada beberapa hal dalam menentukan berpengalaman tidaknya seorang pengusaha yang sekaligus sebagai indikator pengalaman kerja yaitu:

1. Lama waktu/masa kerja.

Ukuran tentang lama waktu atau masa kerja yang telah ditempuh seseorang dapat memahami tugas-tugas suatu pekerjaan dan telah melaksanakan dengan baik.

1. Tingkat pengetahuan dan keterampilan yang dimiliki Pengetahuan dilihat dari konsep, prinsip, prosedur, kebijakan atau informasi lain yang dibutuhkan oleh karyawan. Pengetahuan juga mencakup kemampuan untuk memahami dan menerapkan informasi pada tanggungjawab pekerjaan. Sedangkan keterampilan dilihat dari kemampuan fisik yang dibutuhkan untuk mencapai atau menjalankan suatu tugas atau pekerjaan.

2. Penguasaan terhadap pekerjaan dan peralatan. Tingkat penguasaan seseorang dalam pelaksanaan aspek-aspek tehnik peralatan dan tehnik pekerjaan. Pengalaman berusaha terjadi karena adanya kesempatan kerja yang timbul karena adanya investasi dan usaha untuk memperluas kesempatan kerja ditentukan oleh laju pertumbuhan investasi, pertumbuhan penduduk dan angkatan kerja. Strategi pembangunan yang diterapkan juga akan mempengaruhi usaha perluasan kesempatan kerja.

\section{Bahan Bakar}

Uraian dari Eka (2015) menyebutkan bahwa bahan bakar merupakan salah satu bagian penting dalam melakukan suatu proses produksi, contohnya bahan bakar seperti LPG (Liquid Petroleum Gas), minyak tanah, premium dan lain-lain. Bahan bakar yaitu segala sesuatu yang dapat dibakar. Bahan bahan yang dapat dibakar misalnya: kertas, kayu, kain, minyak tanah, bensin, gas, batu bara, dan lain-lain.

Minyak adalah bahan bakar lain yang ditemukan dalam batuan bumi. Minyak terbuat dari makhluk laut kecil yang hidup pada jutaan tahun yang lalu. Ketika makhluk hidup itu mati, ia terbenam di dasar laut dan terkubur dalam pasir dan lumpur. Jutaan tahun kemudian, sisa-sisa makhluk hidup tersebut berubah menjadi tetes-tetes minyak. Bahan bakar minyak atau BBM adalah salah satu jenis bahan bakar. Dalam penelitian ini Bahan Bakar Minyak 
(BBM) yang dimaksud adalah bahan bakar jenis cair berupa solar dan premium (Laksana, 2014). Maka untuk menggerakkan peralatan, dan terdapat mobilisasi kegiatan diperlukan bahan bakar.

\section{Tingkat Keuntungan}

Menurut Manurung (2007) dalam Nayaka dan Kartika, (2018) dalam membangun sebuah bisnis dibutuhkan dana atau dikenal dengan modal. Bisnis yang dibangun tidak akan berkembang tanpa didukung dengan modal, sehingga modal dapat dikatakan menjadi jantungnya bisnis yang dibangun tersebut. Maka dari itu, adanya modal akan mempengaruhi pendapatan yang akan diterima. Modal dengan kuantitas yang besar dapat memberikan peluang jumlah keuntungan yang besar pula dibandingkan dengan keadaan jumlah modal yang relatif kecil. Apabila modal meningkat maka produksi akan meningkat sehingga dapat meningkatkan pendapatan (Fachrizal, 2016).

Jumlah pendapatan sangat penting karena ia bukti usaha berjalan terus atau tidak. Ia diperoleh berbagai faktor produksi yang digunakan untuk menghasilkan sesuatu barang dan pendapatan merupakan unsur yang paling penting dalam sebuah perusahaan maupun lembaga keuangan karena pendapatan akan dapat menentukan maju mundurnya suatu perusahaan.

\section{METODE PENELITIAN}

\section{Waktu dan Lokasi}

Penelitian ini dilaksanakan pada bulan Agustus sampai dengan bulan Oktober 2019 di Kecamatan Wolio dan Kecamatan Murhum Kota Baubau. Penunjukan lokasi tersebut dengan pertimbangan bahwa kedua lokasi tersebut banyak terdapat usaha penampungan kayu.

\section{Populasi dan Sampel}

Populasi pada penelitian ini adalah seluruh para pengusaha penampung kayu di Kecamatan Wolio dan Kecamatan Murhum sebanyak 19 pengusaha berdasarkan survey awal terhadap para pengusaha penampung kayu, 2019. Mengingat jumlah responden kurang dari 100 responden, maka populasi juga jadi sampel, sesuai pendapat Arikunto (1993) bahwa apabila sampel kurang dari 100, lebih baik diambil semua atau sensus. Selanjutnya jika jumlah subyeknya diatas 100 maka dapat diambil antara $10-15 \%$ atau $20-25 \%$ bahkan lebih.

\section{Jenis dan Sumber Data}

Menurut Sugiyono (2003) bahwa jenis data menurut sifatnya sebagai berikut:

a. Data Kualitatif

Data kualitatif adalah data yang tidak berbentuk angka atau dengan kata lain data yang berbentuk kalimat, kata atau gambar.

b. Data Kuantitatif

Data kuantitatif adalah data yang berbentuk angka. Data kuantitatif dapat dibedakan menjadi dua yaitu data diskrit dan data kontinum. Data diskrit adalah data yang diperoleh dari hasil menghitung. Sedangkan, data kontinum adalah data yang diperoleh dari hasil pengukuran.

Arikunto (2013) menyatakan bahwa sumber data adalah subjek darimana data dapat diperoleh. Sumber data dari penelitian ini adalah menggunakan data primer dan data sekunder. Data primer adalah data yang langsung diperoleh dari para pengusaha penampung 
kayu. Menurut Joko (2015) bahwa data skunder adalah data yang diperoleh dari sumber eksternal dan internal. Data sekunder diperoleh dari badan terkait atau Dinas Kehutanan Provinsi Sulawesi Tenggara yang meliputi atau membawahi UPTD KPH Unit Wakonti Kota Baubau, UPTD KPH Unit 2 Lasalimu, dan UPTD KPH Unit Kapontori.

\section{Variabel Penelitian}

Variabel penelitian ini dibagi sebagai berikut:

1. Variabel independen (X), ada 4 (empat) variabel yaitu: modal, jumlah tenaga kerja, lama berusaha dan jumlah bahan bakar.

2. Variabel dependen (Y), yaitu tingkat keuntungan pengusaha kayu.

\section{Teknik Analisis Data}

Teknis analisis data menggunakan regresi linear berganda untuk menguji pengaruh beberapa variabel bebas $\left(\mathrm{X}_{\mathrm{i}}\right)$ terhadap variabel terikat $(\mathrm{Y})$, dan teknik mengujinya digunakan 2 (dua) baik secara parsial atau uji satu antara variabel $\mathrm{X}_{1}$, terhadap $\mathrm{Y}, \mathrm{X}_{2}$ terhadap $\mathrm{Y}, \mathrm{X}_{3}$ terhadap $\mathrm{Y}$ dan $\mathrm{X}_{4}$ terhadap $\mathrm{Y}$. Uji secara parsial ini untuk menyelesaikan tujuan penelitian 1 . Uji pengaruh secara simultan atau bersama-sama yaitu $\mathrm{X}_{1}, \mathrm{X}_{2}, \mathrm{X}_{3}$, dan $\mathrm{X}_{4}$ terhadap $\mathrm{Y}$ untuk menyelesaikan tujuan penelitian yang ke-2 digunakan uji F. Pada penelitian ini akan dibantu dengan program Statistik Program Sosial Science (SPSS) Versi 21.

Adapun persamaan regresi linear berganda adalah sebagai berikut:

$Y=a+b_{1} X_{1}+b_{2} X_{2}+b_{3} X_{3}+b_{4} X_{4}+e$

Keterangan:

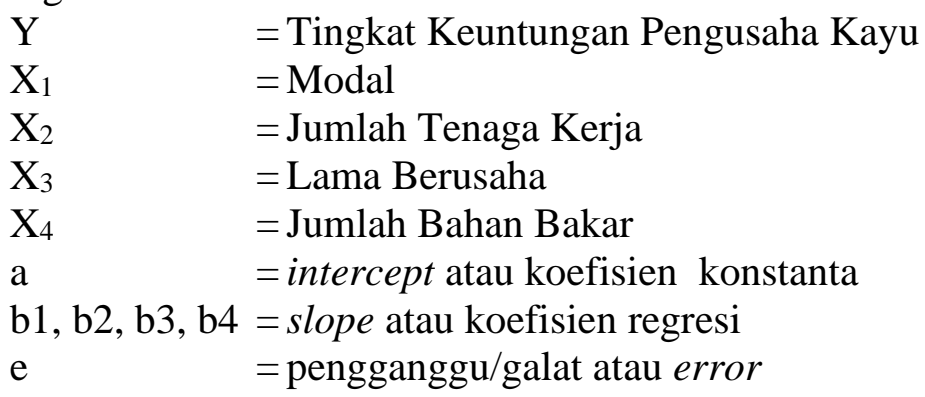

a. Uji dengan statistik F (signifikansi simultan).

Pengujian ini dilakukan untuk melihat pengaruh variabel bebas terhadap variabel tidak bebas secara serentak. Uji ini dilakukan untuk membandingkan pada tingkat nilai signifakansi dengan nilai $\alpha(5 \%)$ pada tingkat derajat $5 \%$.

Pengambilan kesimpulannya adalah dengan melihat nilai sig $\alpha(5 \%)$ atau 0,05 dengan ketentuan sebagai berikut:

a) Jika nilai $\mathrm{Sig}<\alpha(0,05)$ maka $\mathrm{H}_{0}$ ditolak

b) Jika nilai Sig $>\alpha(0,05)$ maka $\mathrm{H}_{0}$ diterima.

Nilai F hitung diformulasikan sebagai berikut:

$$
\mathrm{F}_{\text {hitung }}=\frac{\frac{R^{2}}{\mathrm{k}-1}}{\frac{1-R^{2}}{\mathrm{n}-\mathrm{k}}}
$$


Keterangan:

$$
\begin{aligned}
& \mathrm{R}^{2}=\text { Koefisien determinan } \\
& \mathrm{k}=\text { Jumlah variable independen termasuk konstanta } \\
& \mathrm{n}=\text { Banyaknya data }
\end{aligned}
$$

Hipotesis yang digunakan untuk uji $\mathrm{F}$ sebagai berikut:

$\mathrm{H}_{0}: \beta 1=\beta 2=\ldots . .=\beta \mathrm{n}=0$ (tidak ada pengaruh)

$\mathrm{H}_{1}: \beta 1 \neq \beta 2 \neq \ldots \ldots \neq \beta \neq 0$ (ada pengaruh dan signifikan)

Bila nilai Fhitung < Ftabel, maka Ho diterima dan bila nilai Fhitung > Ftabel, maka Ho ditolak yang berarti bahwa variabel bebas ada pengaruh secara bersama-sama.

b. Uji dengan statistik t (signifikansi parsial)

Uji statistik $\mathrm{t}$ ini dilakukan untuk melihat pengaruh variabel bebas terhadap variabel tidak bebas secara parsial atau uji satu satu dengan derajat keabsahan 5\% (0.05). Pengambilan kesimpulannya adalah dengan melihat nilai signifikansi yang dibandingan dengan nilai $\alpha$ $(5 \%)$ dengan ketentuan sebagai berikut:

a) Jika nilai $\mathrm{Sig}<\alpha(0,05)$ maka $\mathrm{H}_{0}$ ditolak

b) Jika nilai $\mathrm{Sig}>\alpha(0,05)$ maka $\mathrm{H}_{0}$ diterima.

Nilai $t$ untuk mengetahui pengaruh masing-masing variabel bebas terhadap variabel tidak bebas dengan rumus sebagai berikut:

$\mathrm{t}_{\text {hitung }}=\frac{\beta \mathrm{t}}{\mathrm{Se} \beta \mathrm{t}}$

Keterangan:

$\mathrm{Bt}=$ Koefisien regresi

Se $\beta \mathrm{t}=$ Penyimpangan baku

Hipotesis yang digunakan untuk uji t dapat dirumuskan sebagai berikut:

Ho : $\beta 1 \leq 0$ tidak ada pengaruh terhadap produksi

Ha : $\beta 1>0$ ada pengaruh terhadap produksi

Bila nilai $\mathrm{t}$ hitung $<\mathrm{t}$ tabel maka Ho diterima dan bila nilai $\mathrm{t}$ hitung $>\mathrm{t}$ tabel maka Ho ditolak yang berarti bahwa variabel yang bersangkutan ada pengaruh yang signifikan (Fachrizal, 2016).

c. Koefisien Determinasi

Koefisien determinasi $\left(\mathrm{R}^{2}\right)$ adalah untuk mengukur seberapa jauh kemampuan model dalam menerangkan variasi variabel terikat. Nilai koefisien determinasi adalah antara 0 (nol) dan 1 (satu). Jika nilai koefisien determinasi kecil berarti kemampuan variabelvariabel bebas dalam menjelaskan variasi variabel terikat amat terbatas. Nilai yang mendekati satu berarti variabel-variabel bebas memberikan hampir semua informasi yang dibutuhkan untuk memprediksi variasi variabel terikat.

d. Menghitung tingkat keuntungan dengan formulasi sebagai berikut:

$\pi=\mathrm{TR}-\mathrm{TC}$

Keterangan:

$\Pi=$ Profit/laba

$\mathrm{TR}=$ Total Revenue (Total penerimaan dari penjualan)

$\mathrm{TC}=$ Total Cost $($ Total biaya yang dikeluarkan $)$ 
Total revenue adalah penerimaan total produsen dari hasil penjualan hasil outputnya sehingga $\mathrm{TR}=$ output $\mathrm{x}$ harga jual. Sedangkan total cost adalah total biaya yang dilakukan untuk memproduksi output yang dipengaruhi oleh dua variabel biaya tetap. Biaya tetap adalah biaya yang dikeluarkan sesuai dengan jumlah output yang di produksi (Afifah, 2012).

\section{HASIL DAN PEMBAHASAN}

\section{Keadaan Umum Wilayah Penelitian}

Secara astronomis, Kota Baubau terletak di bagian selatan garis khatulistiwa diantara $5.21^{0}-5.33^{0}$ Lintang Selatan dan diantara $22.30^{\circ}-122.47^{0}$ Bujur Timur. Berdasarkan letak geografisnya, Kota Baubau memiliki batas-batas sebagai berikut:

- Sebelah Utara berbatan dengan Kabupaten Buton

- Sebelah Timur berbatasan dengan Kabupaten Buton

- Sebelah Selatan berbatasan dengan Kabupaten Buton Selatan.

- Sebelah Barat berbatasan dengan Selat Buton.

Sepintas tentang letak wilayah Kota Baubau dapat dilihat pada Gambar 1.

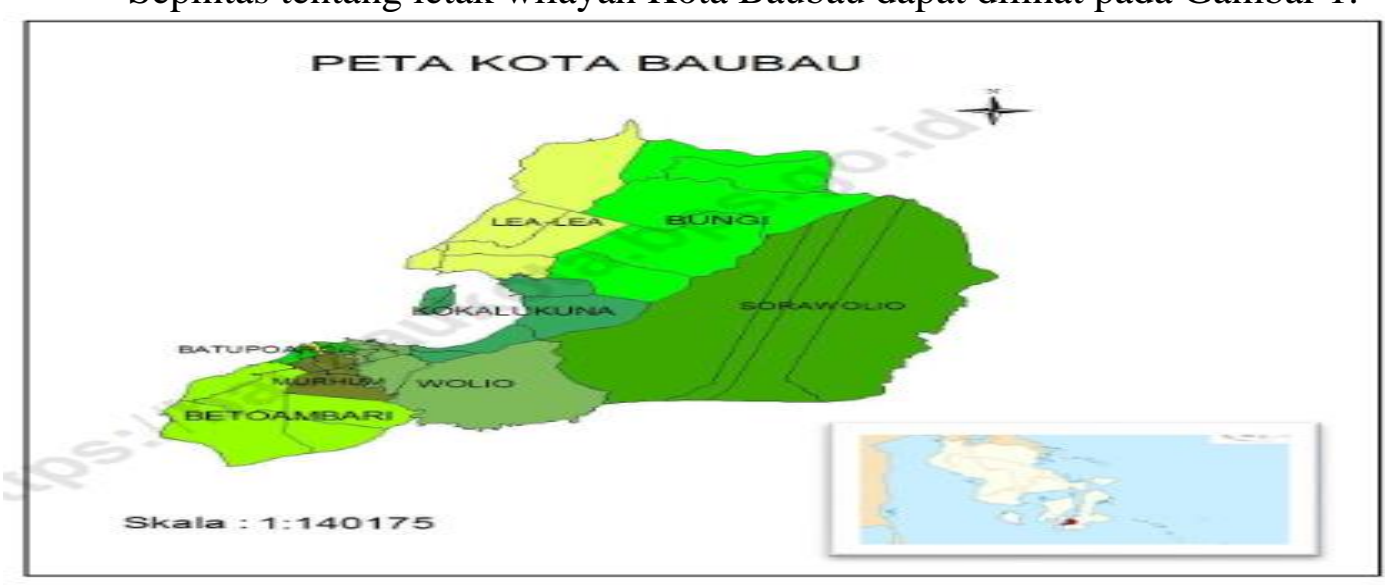

Gambar 1. Peta Kota Baubau (Sumber: Kota Baubau Dalam Angka Tahun 2018).

Tabel 1. Luas Kota Baubau Per Kecamatan Tahun 2018

\begin{tabular}{clc}
\hline No. & \multicolumn{1}{c}{ Kecamatan } & Luas $\mathrm{km}^{2}$ \\
\hline 1. & Betoambari & 32,85 \\
\hline 2. & Murhum & 6,13 \\
\hline 3. & Batupoaro & 1,68 \\
\hline 4. & Wolio & 33,89 \\
\hline 5. & Kokalukuna & 16,81 \\
\hline 6. & Sorawolio & 111,78 \\
\hline 7. & Bungi & 58,89 \\
\hline 8. & Lea-lea & 32,96 \\
\hline & Jumlah & 294,99 \\
\hline
\end{tabular}

Sumber: Kota Baubau Dalam Angka Tahun 2018.

Luas wilayah Kota Baubau mengalami perubahan menjadi 294,99 $\mathrm{km}^{2}$. Salah satu faktor penyebab pertambahan luas Kota Baubau adalah reklamasi pantai yang terjadi di sekitar Kecamatan Wolio dan Kecamatan Batupoaro. 


\section{Pembahasan}

\section{A. Uji secara Parsial (Uji t)}

Penelitian dianalisis berdasarkan tujuan yang telah ditetapkan. Uji $t$ untuk menganalisis tujuan 1 penelitian yaitu akan menguji apakah terdapat pengaruh antara variabel modal $\left(\mathrm{X}_{1}\right)$, jumlah tenaga kerja $\left(\mathrm{X}_{2}\right)$, lamanya berusaha $\left(\mathrm{X}_{3}\right)$ dan jumlah bahan bakar $(\mathrm{X} 4)$ masing-masing terhadap tingkat keuntungan (Y) pengusaha kayu di Kota Baubau. Rincian jelasnya dapat dilihat pada Tabel 2.

Tabel 2. Hasil Uji t

\begin{tabular}{|c|c|c|c|c|c|c|}
\hline & \multirow[t]{2}{*}{ Model } & \multicolumn{2}{|c|}{ Unstandardized Coefficients } & \multirow{2}{*}{$\begin{array}{c}\text { Standardized } \\
\text { Coefficients }\end{array}$} & \multirow[t]{2}{*}{$\mathrm{t}$} & \multirow[t]{2}{*}{ Sig. } \\
\hline & & B & Std. Error & & & \\
\hline \multirow[t]{5}{*}{1} & (Constant) & 20312718.888 & 17129982.068 & & 1.186 & .255 \\
\hline & Modal & .196 & .075 & .624 & 2.614 & .020 \\
\hline & Jumlah Tenaga Kerja & -3181408.425 & 3885717.944 & -.238 & -.819 & .427 \\
\hline & Lama Berusaha & 217296.845 & 887877.823 & .058 & .245 & .810 \\
\hline & Jumlah Bahan Bakar & .164 & .704 & .064 & .233 & .819 \\
\hline
\end{tabular}

Tabel 2 menunjukkan persamaan regresi antara variabel dependent dengan variabel independent sebagai berikut:

$$
Y=20312718.888+0,196 X_{1}-3181408,425 X_{2}+217296,845 X_{3}+0,164 X_{4}
$$

Keterangan:

$$
\begin{aligned}
& \mathrm{Y}_{1}=\text { Tingkat Keuntungan Pengusaha Kayu (Rupiah) } \\
& \mathrm{X}_{1}=\text { Modal (rupiah) } \\
& \mathrm{X}_{2}=\text { Jumlah Tenaga Kerja (orang) } \\
& \mathrm{X}_{3}=\text { Lamanya Berusaha (tahun) } \\
& \mathrm{X}_{4}=\text { Jumlah Bahan Bakar (liter) }
\end{aligned}
$$

Konstanta sebesar 20312718.888 menyatakan bahwa, jika modal, jumlah tenaga kerja, lamanya berusaha dan jumlah bahan bakar tidak ada, maka tingkat keuntungan pengusaha kayu adalah 20312718.888 rupiah. Nilai koefisien regresi $\mathrm{X}_{1}$ sebesar 0,196 menyatakan bahwa setiap penambahan (karena tanda + ) 1 rupiah modal pengusaha kayu, maka akan meningkatkan keuntungan pengusaha kayu sebesar 0,196 rupiah.

Koefisien regresi $\mathrm{X}_{2}$ sebesar 3181408,425 menyatakan bahwa setiap pengurangan (karena tanda -) 1 jumlah tenaga kerja (orang) akan mengurangi tingkat keuntungan pengusaha kayu sebesar 3181408,425 rupiah. Koefisien regresi $X_{3}$ sebesar 217296,845 menyatakan bahwa setiap penambahan (karena tanda + ) 1 tahun lamanya berusaha, maka akan meningkatkan keuntungan pengusaha kayu sebesar 217296,845 rupiah. Untuk Koefisien regresi $\mathrm{X}_{4}$ sebesar 0,164 menyatakan bahwa setiap penambahan (karena tanda + ) 1 liter bahan bakar maka akan meningkatkan keuntungan sebesar 0,164 rupiah. 


\section{Analisa Pengaruh Modal $\left(\mathrm{X}_{1}\right)$ Terhadap Tingkat Keuntungan Pengusaha Kayu (Y)}

Hasil analisa regresi linear berganda, untuk mengetahui pengaruh modal terhadap tingkat keuntungan pengusaha kayu di Kota Baubau dapat melalui uji t atau nilai Sig. (signifikance) seperti terdapat pada Tabel 2. yaitu menunjukkan nilai:

\section{Sig. $=0,020$ atau probabilitas lebih kecil dari 0,05.}

Hal ini menunjukkan bahwa faktor modal memberikan pengaruh secara positif signifikan terhadap tingkat keuntungan pengusaha kayu di Kota Baubau, karena memberikan nilai t hitung bertanda positif yaitu 2,614, sementara nulai t table yaitu 2,10982 dan nilai sig. $=0,02$ lebih kecil dari 0,05. Artinya pada saat jumlah modal yang digunakan untuk berusaha kayu naik, maka tingkat keuntungan pengusaha kayu juga akan meningkat.

Besarnya modal yang dimiliki para pengusaha kayu, akan sangat berpengaruh terhadap produksi maupun produktivitas pengusaha kayu. Adanya pesanan atau order dalam jumlah yang besar, jika tidak di dukung dengan modal yang besar pula, jelas tidak akan dapat memenuhi pesanan tersebut yang berakibat pada fungsi pelayanan yang tidak optimal. Pengusaha dengan modal kerja yang lebih banyak dapat menyediakan bahan baku dan faktor produksi lainnya secara memadai. Modal yang lebih besar juga dapat mengurangi resiko kekurangan modal apabila pelanggan dengan cara memesan kayu dan belum dilunasi sekaligus dan biasanya hal ini terjadi karena ada saling percaya satu sama lain.

Menurut Gideon (2013) dalam Komang dan Kartika, (2018) bahwa modal adalah salah satu faktor produksi yang penting adalah modal, karena tanpa modal kegiatan usaha tidak akan dapat berjalan dengan baik seperti yang diharapkan oleh para pengusaha baik kecil maupun besar. Untuk dapat memenuhi kewajiban terhadap tenaga kerja saja, maka pengusaha harus memberikan upah yang diperoleh dari modal untuk membayarnya. Karena itu, modal harus

dimaksimalkan dengan baik kegunaannya.

\section{Analisa Pengaruh Tenaga Kerja $\left(\mathrm{X}_{2}\right)$ Terhadap Tingkat Keuntungan Pengusaha Kayu (Y)}

Hasil analisa regresi linear berganda, untuk mengetahui pengaruh jumlah tenaga kerja terhadap tingkat keuntungan pengusaha kayu di Kota Baubau dapat melalui uji $\mathrm{t}$ atau nilai Sig. (signifikance) seperti terdapat pada Tabel 4. yaitu menunjukkan nilai:

Sig. $=0,427$ atau probabilitas lebih besar dari 0,05.

Hal ini menunjukkan bahwa faktor jumlah tenaga kerja memberikan pengaruh secara negatif dan tidak signifikan terhadap tingkat keuntungan pengusaha kayu di Kota Baubau, karena memberikan nilai t hitung bertanda negatif yaitu $-0,819$, sementara nilai $t$ tabel yaitu 2,10982 dan nilai sig. $=0,427$ lebih besar dari 0,05. Artinya pada saat jumlah tenaga kerja yang digunakan untuk berusaha kayu naik, maka tingkat keuntungan pengusaha kayu juga akan menurun.

Tenaga kerja merupakan salah satu faktor yang memberikan keuntungan pada pengusaha kayu, yang perlu diperhatikan adalah jumlahnya yang cukup, bukan saja dilihat dari ketersediannya tapi kualitas dan lamanya bekerja sesuai dengan waktu yang telah ditentukan. Setiap proses produksi harus disediakan tenaga kerja yang cukup memadai, jumlah tenaga kerja yang digunakan harus disesuaikan dengan kebutuhan sampai tingkat tertentu sehingga hasil yang diharapkan dapat optimal. Hal ini sesuai dengan Rizki (2017) yang menyebut bahwa setiap proses produksi harus disediakan tenaga kerja yang cukup memadai, dan jumlah tenaga kerja yang digunakan harus disesuaikan dengan kebutuhan sampai tingkat tertentu sehingga optimal. 
3. Analisa Pengaruh Lamanya Berusaha $\left(\mathrm{X}_{3}\right)$ Terhadap Tingkat Keuntungan Pengusaha Kayu (Y)

Hasil analisa regresi linear berganda, untuk mengetahui pengaruh lamanya berusaha terhadap tingkat keuntungan pengusaha kayu di Kota Baubau dapat melalui uji t atau nilai Sig. (signifikance) seperti terdapat pada Tabel 4. yaitu menunjukkan nilai:

Sig. $=0,810$ atau probabilitas lebih besar dari 0,05 .

Hal ini menunjukkan bahwa faktor lama berusaha memberikan pengaruh secara positif dan tidak signifikan terhadap tingkat keuntungan pengusaha kayu di Kota Baubau, karena memberikan nilai t hitung bertanda positif yaitu 0.245 , sementara nilai t tabel yaitu 2,10982 dan nilai sig. $=0,810$ lebih besar dari 0,05. Artinya pada saat lamanya berusaha yang digunakan untuk berusaha kayu naik, maka tingkat keuntungan pengusaha kayu juga akan akan naik karena searah dengan variabel $\mathrm{Y}$ walaupun konstribusinya sangat kecil. Padahal menurut Fachmi (2014), tingkat kecakapan manajemen yang baik ini juga sangat dipengaruhi oleh pengalaman atau lama berusaha seorang pedagang.

4. Analisa Pengaruh Jumlah Bahan Bakar $\left(\mathrm{X}_{4}\right)$ Terhadap Tingkat Keuntungan Pengusaha Kayu (Y)

Hasil analisa regresi linear berganda, untuk mengetahui pengaruh jumlah bahan bakar terhadap tingkat keuntungan pengusaha kayu di Kota Baubau dapat melalui uji $\mathrm{t}$ atau nilai Sig. (signifikance) seperti terdapat pada Tabel 4. yaitu menunjukkan nilai:

Sig. $=0,819$ atau probabilitas lebih besar dari 0,05 .

Hal ini menunjukkan bahwa faktor jumlah bahan bakar memberikan pengaruh secara positif dan tidak signifikan terhadap tingkat keuntungan pengusaha kayu di Kota Baubau, karena memberikan nilai t hitung bertanda positif yaitu 0.33 , sementara nilai $t$ tabel yaitu 2,10982 dan nilai sig. $=0,819$ lebih besar dari 0,05. Artinya pada saat jumlah bahan bakar yang digunakan untuk berusaha kayu naik, maka tingkat keuntungan pengusaha kayu juga akan akan naik karena searah dengan variabel $\mathrm{Y}$ walaupun konstribusinya sangat kecil akibat nilai t hitung lebih kecil dari t tabel.

Hasil ini menunjukkan penggunaan bahan bakar di lokasi penelitian masih dalam jumlah yang terbatas. Padahal menurut Eka (2015) bahwa bahan bakar merupakan salah satu bagian penting dalam melakukan suatu proses produksi, contohnya bahan bakar seperti LPG (Liquid Petroleum Gas), minyak tanah, premium dan lain-lain.

\section{B. Uji secara Simultan (Uji F)}

Uji F digunakan untuk mengetahui secara bersama-sama "simultan" pengaruh variabel bebas (modal, jumlah tenaga kerja, lama berusaha dan jumlah bahan bakar) terhadap variabel terikat (tingkat keuntungan pengusaha kayu) di Kota Baubau. Signifikan dan pengaruh positif dapat di estimasi dengan membandingkan $\mathrm{P}$ value dengan nilai $\alpha=0,05$ atau $\mathrm{F}$ hitung dan $\mathrm{F}$ tabel. Berikut ini perhitungan statistik anova uji F dapat di lihat pada Tabel 3.

Tabel 3. Hasil Uji F

\begin{tabular}{lcccccc}
\hline Model & Sum of Squares & df & Mean Square & F & Sig. \\
\hline 1 & Regression & 3113556238895529.000 & 4 & 778389059723882.200 & 2.097 & $.136^{b}$ \\
\cline { 2 - 5 } & & & & & & \\
\cline { 3 - 6 } & Residual & 5197521529525523.000 & 14 & 371251537823251.600 & & \\
\hline
\end{tabular}


Berdasarkan Tabel 3, menunjukkan variable bebas yaitu modal, jumlah tenaga kerja, lama berusaha dan jumlah bahan bakar secara simultan tidak berpengaruh terhadap variable terikat berupa tingkat keuntungan pengusaha kayu di Kota Baubau, karena memberikan nilai $\mathrm{F}$ hitung bertanda positif yaitu 2,097, sementara nilai $\mathrm{F}$ table yaitu 2,27 dan nilai sig. $=0,136$ lebih besar dari 0,05. Artinya pada saat modal, jumlah tenaga kerja, lama berusaha dan jumlah bahan bakar secara simultan meningkat, maka tingkat keuntungan pengusaha kayu juga akan naik searah dengan variable $\mathrm{Y}$ walaupun konstribusnya sangat kecil, akibat nilai $\mathrm{F}$ hitung lebih kecil dar F tabel.

Hasil pengujian memperlihatkan koefisien determinan $\left(\mathrm{R}^{2}\right)$ sebesar 0,375 . Ini berarti faktor-faktor yang diukur dalam penelitian ini hanya memberikan pengaruh atau kontribusi sebesar $37,5 \%$, sedangkan sisanya dipengaruhi oleh faktor-faktor lain di luar model yang dipilih dalam penelitian ini. Hal ini diperlihatkan oleh Tabel 4.

Tabel 4. Kefisien Determinan $\left(\mathrm{R}^{2}\right)$

\begin{tabular}{|c|c|c|c|c|}
\hline \multicolumn{5}{|c|}{ Model Summary } \\
\hline Model & $\mathrm{R}$ & R Square & Adjusted R Square & Std. Error of the Estimate \\
\hline 1 & $.612^{\mathrm{a}}$ & .375 & .196 & 19267888.774 \\
\hline
\end{tabular}

a. Predictors: (Constant), Jumlah Bahan Bakar, Lama Berusaha, Modal, Jumlah Tenaga Kerja

b. Dependent Variable: Tingkat Keuntungan

\section{Kesimpulan}

\section{KESIMPULAN DAN SARAN}

Berdasarkan hasil penelitian, maka dapat disajikan kesimpulan sebagai berikut:

1. Modal memberikan pengaruh secara positif dan signifikan terhadap tingkat keuntungan pengusaha kayu di Kota Baubau sehingga ketersediaan modal sangat penting. Sedangkan jumlah tenaga kerja, lama berusaha dan jumlah bahan bakar masing-masing tidak memberikan pengaruh terhadap tingkat keuntungan pengusaha kayu di Kota Baubau, karena ketiga variabel tersebut tidak dianggap sebagai faktor utama oleh para pengusaha dalam meningkatkan tingkat keuntungan.

2. Secara simultan modal, jumlah tenaga kerja, lama berusaha dan jumlah bahan bakar tidak berpengaruh terhadap tingkat keuntungan pengusaha kayu sebab nilai Adjusted $\mathrm{R}^{2}$ sebesar 0,375 berarti faktor-faktor yang diukur dalam penelitian hanya berpengaruh sebesar $37,5 \%$ terhadap terhadap keuntungan pengusaha kayu.

\section{Saran}

Adapun saran-saran yang dapat diberikan sehubungan dengan penelitian ini adalah:

1. Kepada pengusaha kayu di Kota Baubau agar dapat mengelola usahanya dengan menggunakan modal sebaik-baiknya untuk kelancaran operasionalisasi usaha. Modal harus 
selalu tersedia apalagi modal lancar dapat meningkatkan usahanya. Jika cukup modal dapat mengembangkan usaha agar lebih besar.

2. Kepada pemerintah agar senantiasa memperhatikan para pengusaha penampung kayu terutama mencarikan solusi dalam hal penyimpanan kayu agar tidak mudah rusak yang pada akhirnya menimbulkan kerugian bagi para pengusaha kayu.

\section{DAFTAR PUSTAKA}

Afifah, F. (2012). Analisis Pengaruh Faktor Modal, Biaya Tenaga Kerja, dan Bahan Baku Terhadap Tingkat Keuntungan Pengusaha Industri Batik di Desa Jarum Kecamatan Bayat Kabupaten Klaten. Skripsi Universitas Sebelas Maret Surakarta.

Arikunto, A., (2013). Prosedur Penelitian. Jakarta: Rineka Cipta.

Biro Pusat Statistik, 2018. Kota Baubau dalam Angka. BPS Baubau.

Eka, P., P., (2015). Analisis Pengaruh Modal, Bahan Baku, Bahan Bakar dan Tenaga Kerja Terhadap Produksi Pada Usaha Tahu di Kota Semarang Tahun 2015. Universitas Diponegoro.

Fachmi, (2014). Analisis Produksi dan Pendapatan Industri Meubel di Kota Makassar.

Fachrizal, R. (2016). Pengaruh Modal dan Tenaga Kerja Terhadap Produksi Industri Kerajinan Kulit di Kabupaten Merauke.. 9(Oktober), 66-75.

Faizal D., F., (2017). Pengaruh Modal Usaha, Lama Usaha, dan Sikap Kewirausahaan Terhadap Pendapatan Pengusaha Lanting di Lemh Duwur Kecamatan Kuwarasan Kabupaten Kebumen. Universitas Negeri Yogyakarta.

Joko, P., S., (2015). Metode Penelitian Dalam Teori dan Praktik. Jakarta: Rineka Cipta. h. 88

Laksana A. (2014) Pengaruh Kenaikan Harga Bahan Bakar Minyak Bersubsidi Tahun 2013 Terhadap Abnormal Return Saham dan Trading Volume Activity Saham Pada Perusahaan Yang Masuk Dalam Indeks LQ-45. Skripsi Program Studi Akutansi Jurusan Pendidikan Akutansi. Fakultas Ekonomi Universitas Negeri Yogyakarta.

Komang W. N., \& Kartika, I. N. (2018). Pengaruh Modal, Tenaga Kerja dan Bahan Baku Terhadap Pendapatan Pengusaha Industri Sanggah di Kecamatan Mengwi. Universitas Udayana Bali.

Marselina, T. R. (2016). Pengaruh Investasi, Unit Usaha dan Tenaga Kerja Terhadap Nilai Produksi Sektor Industri di Provinsi Jambi. 5(1), 1-12.

Rachman, O., J. Malik, (2011). Penggergajian dan Pemesinan Kayu Untuk Industri Perkayuan Indonesia. Jakarta: Balitbang Kehutanan. 
Rizki, Y. A., (2017). Analisis Faktor-faktor yang Mempengaruhi Produksi Industri Furniture Kaca dan Aluminium di Kota Pekan Baru. JOM Fekon, 4(1), 434-444.

Sofyan. (2017). Analisis Pengaruh Modal, Jam Kerja, dan Pengalaman Kerja Terhadap Pendapatan Pengrajin Batu Bata di Desa Bontobiraeng Selatan Kecamatan Bontonompo Kabupaten Gowa. UIN Alaudin Makassar.

Sopianoor, Zuhdi Y., dan M. P. B. (2016). Studi Rendemen Bahan Baku Log Pada IUIPHHK Rusmandiansyah di Kecamatan Damai Kabupaten Kutai Barat Jurnal AGRIFOR, XV(2 Oktober), 289-296.

Sugiyono. (2003), Metode Penelitian Bisni, Edisi 1, CV. Alfabeta, Bandung. (2016). Metode Penelitian Manajemen. Bandung: Alfabeta.

Yustinus, S., 2012. Aspek Kualitas Kayu Dalam Konservasi dan Pemugaran Cagar Budaya Berbahan Kayu Jurnal Konservasi Cagar Budaya Borobudur, Volume 6, Nomor 1, Okotober 2012, Hal 87-93 